\title{
Perception Study on Workspace for Government Office in Malaysia
}

\author{
E.M.A Zawawi ${ }^{1}$, S.N Kamaruzzaman ${ }^{2}$, N.D.M Dahari ${ }^{3}$, R.A Rashid ${ }^{4}$ \\ ${ }^{1,3,4}$ Faculty of Architecture, Planning and Surveying,Universiti Teknologi MARA, 40450 Shah Alam, \\ Selangor, Malaysia \\ ${ }^{2}$ Faculty of Built Environment,Univerisity of Malaya, Lembah Pantai,Kuala Lumpur, Malaysia.
}

\begin{abstract}
Nowadays, office workspaces consist of four (4) different generations; Veterans, Boomers, X-ers and Millenial, which different generation have different preferences. It is essential as Facilities Management Manager to understand the effects of the workspace design satisfactions on the generational of office employee and to improve the office working spaces. This research is focused only for government offices building in Selangor which consisted of ten (10) departments. This study aims to investigate the office workspace configuration that has been implemented in government offices as this influence the satisfaction of the employee and the organisation as a whole a long with creating better office workspace in reaching suitable office workspace. The study is a cross-sectional survey that used self-administered structured questionnaire to the target population of employees. Out of the one hundred and ninety (190) questionnaire administered, one hundred and eighty six (186) questionnaire were obtained constituting $98 \%$ for analysis. Non-parametric of SPSS approach was used to analyse data such as cumulative percentage of Demographic variables, percentage of the elements of workspace design (usability, flexibility, controllability and suitability), the level of employee's satisfaction and the mean rank of the preference of crucial choices in creating better office workspace (Location, Use, Layout, Appearance, Support Spaces and Standardisation). The study develops understanding of which elements of satisfactions of workspace design and the crucial choices in creating better office workspace in providing satisfying design features. The study thereby provides advice for facility management decision making.
\end{abstract}

\section{Introduction}

Nowadays, the workplace has undergone several transformation towards meeting the 25th century. The workplace is made from a numbers of planned zones and workspaces. Mostly, workers spent about eight (8) hours at their workplace more than spending their time at home. It is essential as Facilities Management (FM) Manager to understand the effects of the space management and planning on the office employee and to improve the office working spaces. It is said that employee function within their office working spaces must be study to ensure the workers are productive and high morale. When asking to list the crucial factors which contribute the workspace evolution, many would agree that technology has done many ways on how employee's work [1]. Office working 
spaces design is transform to suit the cordless port and wireless. This evolution of technology allows the worker to be more mobility and virtuality like work at home [2].

Furthermore, the modern furniture has responded to this transformation in workplace with the creation of modular furniture systems which are more flexible, easy to assemble, electrified and customizable [3]. But according to Lindahl [4] found that permanent desk and workstations only be given to those who only occupy them throughout of eight (8) hours working day. He also found that, the qualities of work environment become poor and reflected to the moderately of focusing at the place of work. This is concerned by Sule [5] which physical workplace is the top three of workers' productivity such as employees comfort, access to people and equipment, privacy and flexibility.

This research is aim to study and analyze the office workspace configuration that has been implemented in government offices as this influence the satisfaction of the employee and the organisation as a whole and as well as to create better office workspace in order to enhance the employee's productivity and morale.

\section{Space Management}

Over the years, many organisations have been trying new designs and techniques to construct office buildings, which can increase productivity, and attract more employees. Many authors have noted that, the physical layout of the workspace with efficient management processes is a key role in boosting employees' productivity and improving organisational performance $[6,7,8]$.

A workplace is basically made up of a number of planned zones and workspaces. Space planning, as a discipline, forms a major part of the Facilities Manager's responsibilities [9] which he explained that it is a continuous process resulting from dynamic organisational growth and churn as well as the emerging new work-styles in today's global economy. Whether it is a brand new operation, full office relocation or a part re-organisation, a sensibly planned and implemented workplace can have a reflective impact on the performance of an organisation.

Space use and space planning as recognised by Yang and Chen [10] as areas that can be further improved. Space utilisation rates have not significantly improved over the last decade across the sector as a whole, and space management measures are not always particularly effective. They stated that the estate itself can also have intrinsic constraints, such as poor condition, unsuitable space, designed for different styles of workspace use and research processes, which can influence space use and management.

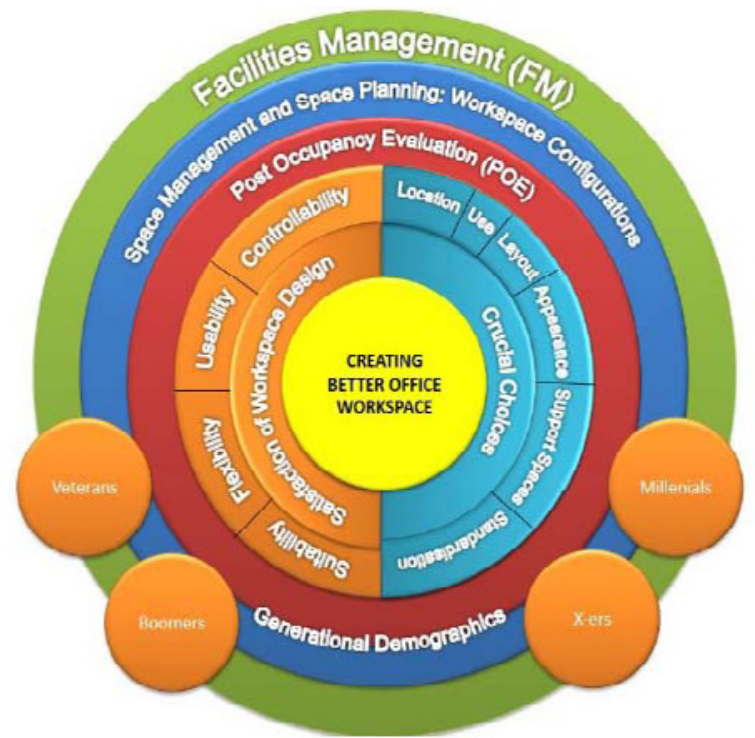

Figure 1: Summary of research study 
There is evidence for good correlation between space use and quality of space. McGregor [11] explained that there are five key areas of focus for improving space management. These are: information, innovation, design, communications and management techniques. A series of detailed measures have been provided under each of these headings, which should help organisation further improve space management.

It is found that there are many criteria needed in the process of creating better workspace in office. The criteria were then summarising as in Figure 1. In general the study will involve a survey on workspace configuration of the occupants in office towards their satisfaction level. This is including suitability, flexibility, usability and controllability. The Crucial Choices part will not be presented in this paper.

\section{Research Methodology}

A cross-sectional survey that used self-administered structured questionnaire was used to the target population of employees in government office in Selangor. Out of the one hundred and ninety (190) questionnaire administered, one hundred and eighty six (186) are usable questionnaire were obtained constituting $98 \%$ for analysis. Non parametric of SPSS approach was used to analysed data such as cumulative percentage of Demograhic variables, percentage of the elements of workspace design (usability, flexibility, controllability and suitability), the level of employees' satisfaction and the mean rank of the preference of crucial choice in creating better office space.

There are 10 department involved in this study. To provide in-depth understanding in Government office workspace, the study of the current office workspace configuration has been made through Government Guidelines and Regulations of Panduan Pengurusan Pejabat No. 5 Tahun 2007 which is stated in Bil.5, Per. 1.19 - Ruang Pejabat specifically explained in Surat Pekeliling Am Bil.14 Tahun 1982 - Perlaksanaan Pejabat Pelan Terbuka [MAMPU (1)] and Guidelines for Building Room Area for Office [UPEN (2)]. Through the study, as stated in the government guideline mostly all the government building offices in Malaysia have already adapted this concept of open plan offices as stated by the Surat Pekeliling Am Bil.14 Tahun 1982 - Perlaksanaan Pejabat Pelan Terbuka [MAMPU(1)]. However, to identify that the department in government office in Selangor are implemented; the observational method is carried out in this study. As stated by the guideline, office workspace configuration is highlighted as the most crucial aspect in order to meet the targets of the organisation. One of the targets is to provide a high productivity of government employees.

However the survey covered aspects of workspace layout, workspace size, surface area, usability of furniture, flexibility of furniture, availability of furniture, meeting room, access to breakout/special space, and access to shared equipment.

\section{Data Analysis and Finding}

As mention in Section 3, data collection covering aspects of workspace layout, workspace size, surface area, usability of furniture, flexibility of furniture, availability of furniture, meeting room, access to breakout/special space, and access to shared equipment. Data was collected by distributing set of questionnaire to the occupants in the office. Out of the 190 questionnaire are sent out, 186 questionnaires were returned representing $98 \%$ of response rate. The characteristic of respondent are presented in Table 1. 
Table 1: Demographic profile of respondents

\begin{tabular}{|c|c|c|c|}
\hline Variables & Categories & $\mathrm{N}$ & $\%$ \\
\hline \multirow[t]{2}{*}{ Gender } & Male & 72 & 38.7 \\
\hline & Female & 114 & 61.3 \\
\hline \multirow[t]{4}{*}{ Races } & Malay & 175 & 94.1 \\
\hline & Indian & 6 & 3.2 \\
\hline & Chinese & 3 & 1.6 \\
\hline & Others & 2 & 1.1 \\
\hline \multirow[t]{5}{*}{ Age } & Below 25 years & 19 & 10.2 \\
\hline & $26-35$ years & 85 & 45.7 \\
\hline & $36-45$ years & 43 & 23.1 \\
\hline & $46-55$ years & 27 & 14.5 \\
\hline & More than 55 years & 12 & 6.5 \\
\hline \multirow[t]{4}{*}{ Born in Year } & 1925 to 1945 (Veterans) & 2 & 1.1 \\
\hline & 1946 to 1964 (Boomers) & 32 & 17.2 \\
\hline & 1965 to 1980 ( $\mathrm{X}$-ers) & 68 & 36.6 \\
\hline & 1981 to 2000 (Millenials) & 84 & 45.2 \\
\hline \multirow[t]{4}{*}{ Job Type } & Managerial/ Executives/ Professional & 31 & 16.7 \\
\hline & Admin/ Clerical & 61 & 32.7 \\
\hline & Technical & 79 & 42.5 \\
\hline & Others & 15 & 8.1 \\
\hline \multirow[t]{4}{*}{ Working Experience } & Less than 1 years & 17 & 9.1 \\
\hline & 1 to 5 years & 37 & 20.4 \\
\hline & 6 to 10 years & 56 & 30.1 \\
\hline & More than 10 years & 75 & 40.3 \\
\hline
\end{tabular}

\subsection{Assessment on workspace configuration and satisfaction}

The workspace layout is rate by all departments with an average rating which the Figure 2 stated that almost to S-shape with only differences between the departments. While the rating profiles of Department Road lean towards a positive rating, while Department of Bahagian Senggara Persekutuan Negeri shows slightly weaker results. Comparing the profiles of other Department of Administrative and Finance, Department of Corporate, Department of Architect, Department of Pendidikan dan Pengajian Tinggi, Department of Electrical, Department of Mechanical, Department of Contract and Quantity Surveying as well as Department of Building suggest that the workspace layout can improve satisfaction of the employees.

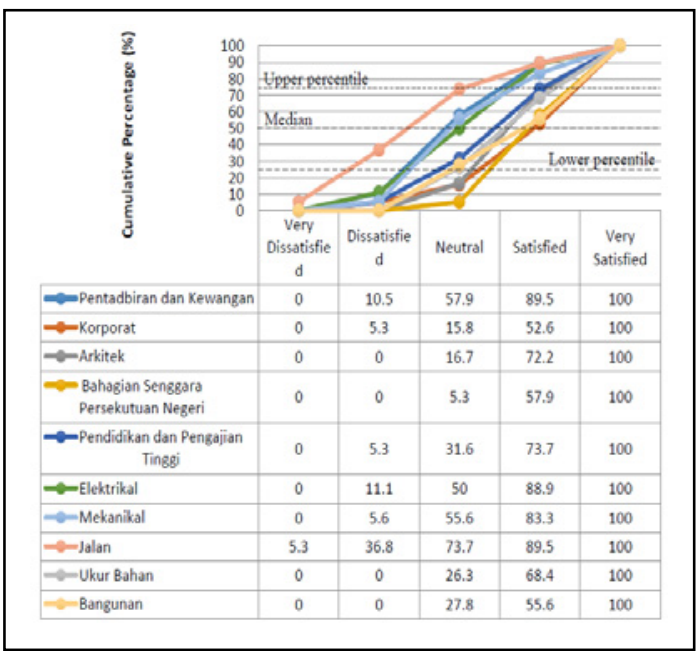

Figure 2: Workspace Layout

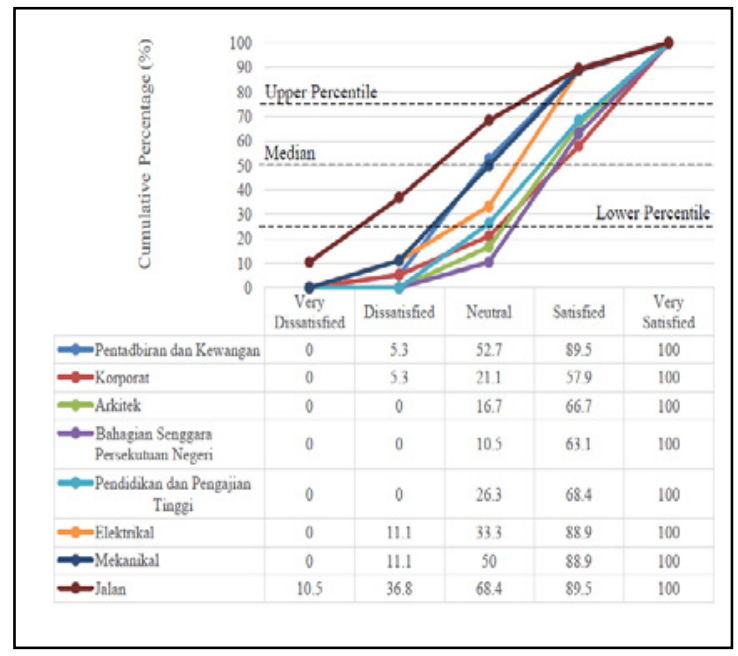

Figure 3: Workspace size 
Figure 3 discussed that the size of the personal workspace is rated by all departments between positive and indifferent. While Department of Road, Administrative and Finance as well as Department of Mechanical and Electrical is more towards upper percentile and rate this aspect with a positive rating, however other Department still rate their positive rating but towards and indifferent ratings. The findings for the size of the personal workspace suggest that Department of Bahagian Senggara Persekutuan Negeri, Department of Architect and Department of Corporate which are currently occupying the department demands of the workspace size are related with the satisfaction of workspace design.

Figure 4 explained that the ratings of the workspace surface area produce similar profiles as the size of the personal workspace. Overall ratings of the workspace surface area for all departments are again the most satisfied with their current workspace surface area and suggesting that this aspect in is generally affect the preferences of the employees satisfactions and needs.

The rating for the usability of furniture produces an average rating which mostly all departments are leans towards the positive side. As stated in Figure 5, Department of Road and Department of Mechanical produce the best rating profiles which are nearly to 5 scale points. However, all profile lines are close together with percentiles and medians on the rating scales. Department of Bahagian Senggara Persekutuan Negeri and Department of Architect are suggesting that the usability of furniture is related positively with aspect of satisfaction of workspace design.

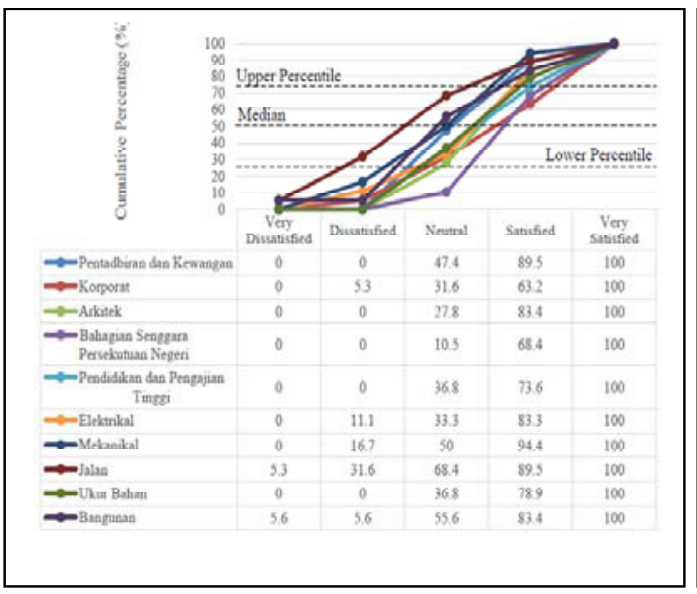

Figure 4: Flexibility of furniture

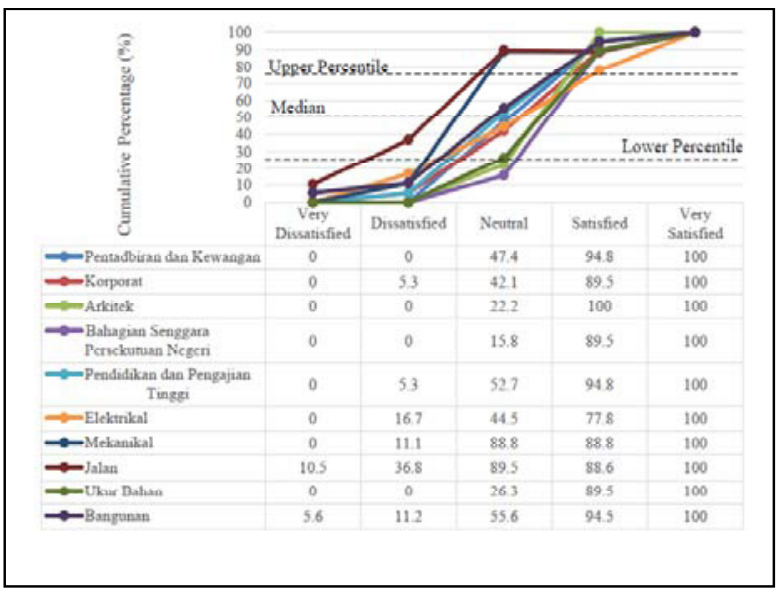

Figure 5: Availability of furniture

The satisfaction with the meeting rooms is rated positively for all departments but weaker for Department of Electrical. It is rated poorly by subjects in Department of Ukur Bahan. All other rating profiles show indifferent assessment of this aspect. This could be due to space constraints or due to lack of demand analysis before the update measures were planned.

The profiles of the assessments of satisfaction with the social spaces show a similar pattern as the profiles of the rating of meeting rooms (Figure 6). The profile for Department of Electrical indicates that this aspect was addressed very successfully in the design of the current office workspace design in access to breakout and social space. This is resulting in 80 per cent of the subjects rating of neutral satisfaction with this aspect. 


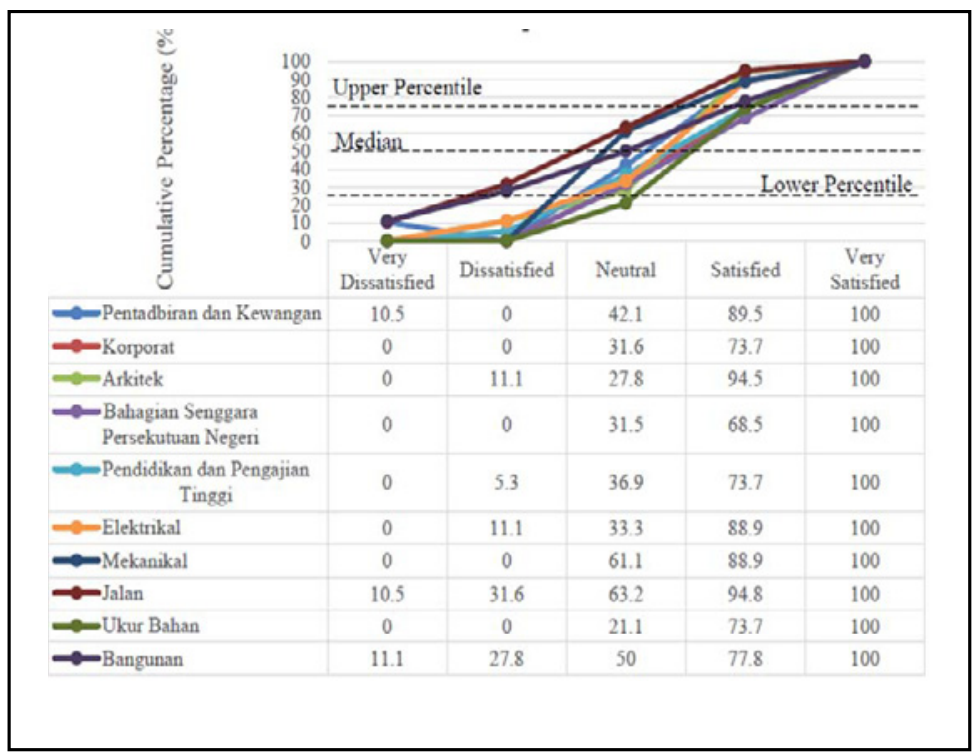

Figure 6: Access to meeting room

Table 2: Descrintive Statistic of satisfaction of current office worksnace

\begin{tabular}{c|l|c|c|c}
\hline No. & Variables & Mean & Mean Rank & Std. Deviation \\
\hline 1. & Workspace Area & 3.9086 & 8.18 & 1.10391 \\
\hline 2. & Workspace Size & 3.7849 & 8.04 & 0.92239 \\
\hline 3. & Workspace Surface Area & 3.7151 & 7.69 & 0.88194 \\
\hline 4. & Usability of Furniture & 3.5645 & 6.97 & 0.81779 \\
\hline 5. & Flexibility of Furniture & 3.5538 & 6.98 & 0.78486 \\
\hline 6. & Availability of Furniture & 3.4301 & 6.38 & 0.91708 \\
\hline 7. & Access to Meeting Room & 3.6613 & 7.58 & 0.95199 \\
\hline 8. & Access to Breakout Space/ Social Space & 3.5376 & 6.92 & 0.93067 \\
\hline 9. & Shared Equipment & 3.4677 & 6.61 & 0.91918 \\
\hline 10. & Availability of Suppress Unwanted Noise & 3.2312 & 5.57 & 0.94457 \\
\hline 11. & Ability to avoid visual/ audio disturbance & 3.2688 & 5.73 & 0.87783 \\
\hline 12. & Access to quite spaces and privacy & 3.1559 & 5.34 & 0.94291 \\
\hline
\end{tabular}

The analysis of the result in Table 2 shows that usability of workspace design for workspace area (8.18) is a most aspect related with satisfaction of the current office workspace compared with the workspace size (8.04) and workspace surface area (7.69). Flexibility of the availability of furniture (6.98) is affected the satisfaction of the employees but the usability of furniture (6.97) is also affected the satisfaction as well as the availability of the furniture (6.38). Usability elements of satisfaction of the workspace design is related to the access to meeting room (7.58) and less affected by the access to breakout space/ social space (6.92) and shared equipment (6.61). Controllability is also the elements of the satisfaction of workspace design which related to the positive rating of the availability of suppress unwanted noise (5.73), ability to avoid visual/ audio disturbance (5.73) and access to quite spaces and privacy (5.34). From the overall descriptive statistic shows that the employees are more concerned about satisfaction of the workspace area. 


\section{Conclusions}

This research uses votes collected from the questionnaire survey on the topic area of satisfaction of current office workspace and creating better office workspace. The votes are collected as answers to the question on "How satisfied are you with these aspects of your current workspace?" on a fivepoint scale between 1 for "Very dissatisfied" and 7 for "Very satisfied". For quantitative assessment the cumulative frequency is used while the results are discussed qualitatively using the values depicted and shape of the curve as indicator for the rating.

The overall results of this research shows that the elements of the satisfaction of the workspace design is relatively related with the satisfaction as well as preferences of the crucial choices is highly related with the creating better office workspace.

There is still need more research with this focus on needs and preferences of office workspace of different generations. It should however, be said that this research has few limitations that have to be taken into account when generalising the results which understanding on generational differences and the crucial choices in creating better office workspace requires longitudinal studies. Additionally, this research only focus on the employee's feedback of their satisfactions on the current office workspace configuration and their preferences of the crucial choices in creating better office workspace, and the impact of these issues were not included in the study.

\section{Acknowledgement}

This research is funded by University of Malaya, Malaysia.

\section{References}

1. Leete, L. (2003). The changing workspace - Trends. BNET Business Network. Retrieved on 10 October 2011.

2. Tyler, G. (1997) Perspective: Welcome to the office hotel. Management Development Review, vol. 10, no. 4/5, pp. 145-147.

3. Stephanie Fanger (2012). Workplace Configuration, How office design affects employee morale and productivity. Retrieved on October 28, 2012 at FMJ website: http://www.fmlink.com/article.cgi?type=Magazine\&title=Workplace $\% 20$ Configuration $\&$ pub $=$ FMJ\&id $=43250 \&$ mode $=$ source

4. Lindahl, G. A. (2004). The innovative workspace: an analytical model focusing on the relationship between spatial and organisational issues. Facilities, vol. 22, no. 9/10, pp. 253-258.

5. Sule, A., (2007) Defining spaces. Times Journal of Construction and Design.

6. Uzee, J (1999), the inclusive approach: creating a place where people want to work. Facility Management Journal of the International Facility Management Association, 26-30.

7. Williams, B. and Roberts, P. (2000). The developing role of the intelligent client. In World Work Place: The evaluation of thought on the modern workplace. Proceedings of the EURO.

8. Leaman, A, Bordass, B (1993), Building design, complexity and manageability, Facilities, 11(9), 16-27.

9. Steiner, J. (2005), the art of space management: Planning flexible workspaces for people. Journal of Facilities Management, vol. 4, no. 1, pp. 6-22.

10. Yang, M.-H. \& Chen, W.-C. (1999). A study on shelf space allocation and management. International Journal Production Economics. 60(61): 309317.

11. McGregor, W.,(2000) "The future of workspace management", Facilities, Vol. 18 Iss: 3/4, pp.138 $-143$ 